\title{
Present Condition of Road Traffic Accident: A Case Study of Rajshahi City, Bangladesh
}

\author{
Md. Mahmud Hasan Mamun \\ Graduated with B.Sc. degree \\ from Rajshahi University of \\ Engineering \& Technology, \\ Rajshahi-6204
}

\author{
Md. Mintu Miah \\ Lecturer, Department of Civil \\ Engineering, Rajshahi \\ University of Engineering \& \\ Technology, Rajshahi-6204
}

\author{
Muhammad Iftiarul Islam \\ Graduated with B.Sc. degree \\ from Rajshahi University of \\ Engineering \& Technology, \\ Rajshahi-6204
}

\begin{abstract}
Road accident is an incisive problem in highway transportation system which directly sentenced to death, injury and property damage. Rajshahi is one of the most crucial cities in Bangladesh where road accident frequently occurs. Many people die and seriously injured every year in Rajshahi city due to accident. The statistical data of road accident of Rajshahi city is presented in this paper. Data of accidents for three years (2011, 2012 \& 2013) were collected from four Police Stations which are situated in Rajshahi city. It is observed that, 51 accidents occur in this time span. It has been found that six intersections and four mid-blocks are the most hazardous, where the rate of accident frequency is high. These intersections and mid-blocks were located by GPS technology and finally a map is drawn by GIS to indicate these locations. The analysis shows that $41.67 \%$ victims were between ages 20 to 35 years old. The vehicles are mostly responsible for accidents that are trucks (26\%) and buses (23\%). Truck accidents caused in city road accidents contribute $32.56 \%$ of total deaths while other vehicles such as Bus $23.26 \%$, Private Car 4.65\%, Auto Rickshaw 9.30\%, Bike $11.63 \%$, Vutvuti $11.63 \%$, Rickshaw/Van 2.33\%, Emma 2.33\% and Micro bus $2.33 \%$ of total fatalities.
\end{abstract}

\section{General Terms}

Accident situation and its analysis issue.

\section{Keywords}

Traffic Accident, Accident Situation, Data Collection, Analysis, Pedestrians, Fatalities, Injuries, Hazardous Intersections, Hazardous Mid-Blocks, Hazardous Map.

\section{INTRODUCTION}

Accident is a catastrophic problem in highway transportation system as it causes property damages, personal injury, death and several severe casualties [1]. Generally, accident occurs due to simultaneous flow of heterogeneous traffic, mixed flow pattern of traffic and pedestrians. The nuisance of road accident is inevitable in daily life. It cannot be totally prevented. However adequate engineering measurement can reduce the occurring of frequent accident in different road intersections and mid-blocks.

A good system of transportation is very essential for rapid industrial and economic growth for any country where roadway, airway, waterway and railway are different modes of transportation among which roadway is most appreciated and in which accident frequently occurs. Statistics show that every year more than 5 million people die due to road traffic accident all over the world [2]. World health organization (WHO), Harvard University and World Bank (WB) simultaneously run a program named "Study Global Burden of Disease" which shows that Road traffic accident was the ninth biggest cause of death in the year of 1990 , however by 2020 , the ninth position of road accident will be raised to the third place [3].

Bangladesh is a developing country of South Asia. It has an area of $147,570 \mathrm{~km}^{2}$ which contains a higher population density of $1,033.5 / \mathrm{km}^{2}[4,5]$. Rajshahi is the important divisional city of Bangladesh. Rajshahi city has well organized internal communication as well as connection to other parts of the country. There are 96 metalled roads with a total length of about $1270 \mathrm{~km}, 108$ semi-metalled roads of about $546 \mathrm{~km}$ length [6]. Almost, 51 accidents occurred in Rajshahi city areas in last three years (2011, 2012 and 2013).

The study area belongs to four Police Stations of Rajshahi city and they are: Boalia Model Police Station, Rajpara Police Station, Shah Mokdum Police Station and Motihar Police Station.

Extensive research works about accident study in Rajshahi city has not been carried out. Some sporadic researches about road traffic investigation at some selected intersection have been conducted where the situation of traffic signals and road marking were shown [7, 8]. All of these researches partially described some particular place of Rajshahi city. They highlighted on traffic congestion, road intersection and midblock design, traffic signal and necessity of Road Island. However, those researches did not measure with a detailed specimen of analysis and did not highlight on road traffic accident and causes of it. Hoque M.M. conducted most scientific and modern research about situation of road accidents in 1981 to 1991 which shows that, about $60 \%$ accidents occur in urban areas and $40 \%$ accidents occur in rural areas of Bangladesh [9]. The methodology used by Hoque M.M. is followed in this paper. A research was performed to describe accident situation in Khulna city where they found that vehicles liable for accidents are trucks (26\%) and buses (23\%) [10]. they also made some recommendation to reduce accident frequency. However, they did not locate the most hazardous places graphically.

The objectives of this study are:

1. To identify the road mid-blocks and intersection where accident occurs frequently, find out the age distribution of victims and type of vehicles involved in accidents.

2. To analysis the loss of human life, property and vehicle damage for different police stations.

3. To find out the maximum accident frequency for particular road mid-blocks and intersections which have been located by GPS device and finally drawn the map by GIS software. 


\section{DATA COLLECTION}

Data of road accidents were collected in two steps. In the initial stage, data on road accidents of Rajshahi city were collected from four Police Stations (Boalia Model Police Station, Motihar Police Station, Rajpara Police Station and Shah Mokdum Police Station) in the city for last three years. The data included Accident Date, Accident Time, Location of the Accident, Collision Type, Number of Vehicles Involved, Number of Deaths, Injury, Cost of Property Damage, Details of Victim, Details of Driver and some more information about how accident occurred. It was found that 12, 20, 7 and 12 accidents occurred in Boalia Model Police Station, Motihar Police Station, Rajpara Police Station and Shah Mokdum Police Station respectively.

After analyzing the accident data, the road intersection and mid-block having maximum frequency of accident is identified. Latitude and longitude are measured in those places by using GPS device in the last stage of data collection. eTrex Vista HCx device was used to measure latitude and longitude of particular location by visiting them. Google Earth-map was used to digitalize the shape-file of our study area. ArcGIS (version 10.1) was used to locate the hazardous intersections and mid-blocks on the map.

\section{DATA ANALYSIS AND DISCUSSIONS}

\subsection{Analysis of Collected Data}

The collected data were analyzed for the age distribution of victims, type of vehicles and intersections and road midblocks subjected to higher frequency of fatal accidents.

\subsection{Age Distribution of Traffic Fatalities and Injuries}

The age distribution of fatalities and injuries among various road user groups is shown in Figure 1(a), 1(b), 1(c) and 1(d) respectively. Variation of ages are presented as abscissa with respect to the percentage of fatalities and injuries involved in accident which is presented as ordinate. Figure 1(a) indicates that, the age group 20 to 35 years account for $42 \%$ of fatalities and injuries for all road user groups. It is also found that $22.22 \%$ fatalities occur in case of ages above 50 years old road user, $13.89 \%$ fatalities occur for ages 36 to 50 and $11.11 \%$ fatalities occur in case of ages below 10 to 19 years old. Figure 1(b) represents that age group >50 years old account for around $33 \%$ of fatalities and injuries for pedestrian road user group. Also it is seen that ages 20 to 35 accounted for $29.17 \%$ of total fatalities and ages 10 to 19 accounted for less which is $8.33 \%$. While Figure 1(c) shows that, the age group 20 to 35 years account for $83 \%$ of fatalities and injuries for motorized road user group. However 10 to 19 years old motorized road users fall in $16.67 \%$ of traffic fatalities. According to Figure 1(c) Road user below 10 year, ages 36 to 50 and above 50 years old are not vulnerable to fatalities and injuries. Also, Figure 1(d) shows that, the age group 20 to 35 years account for $50 \%$ of fatalities and injuries for non-motorized transport (NMT) road user group. 33.33\% fatalities contributed by NMT road user of ages 36 to 50 years old. Beside this NMT road user ages of 10 to 19 years old involved $16.67 \%$ of total traffic fatalities.

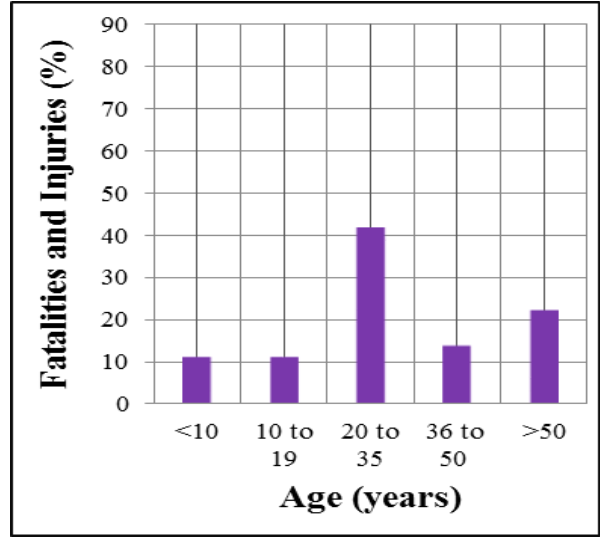

Figure 1(a): Age distribution of total road user with respect to the fatalities and injuries $(\%)$.

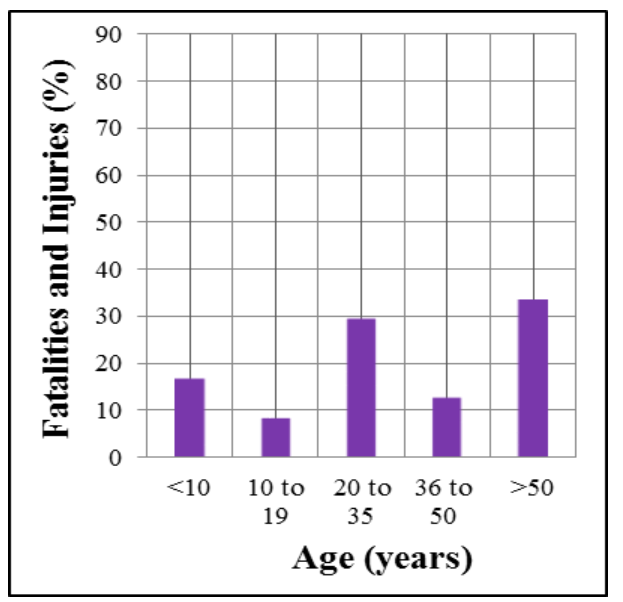

Figure 1(b): Age distribution of pedestrians with respect to the fatalities and injuries (\%).

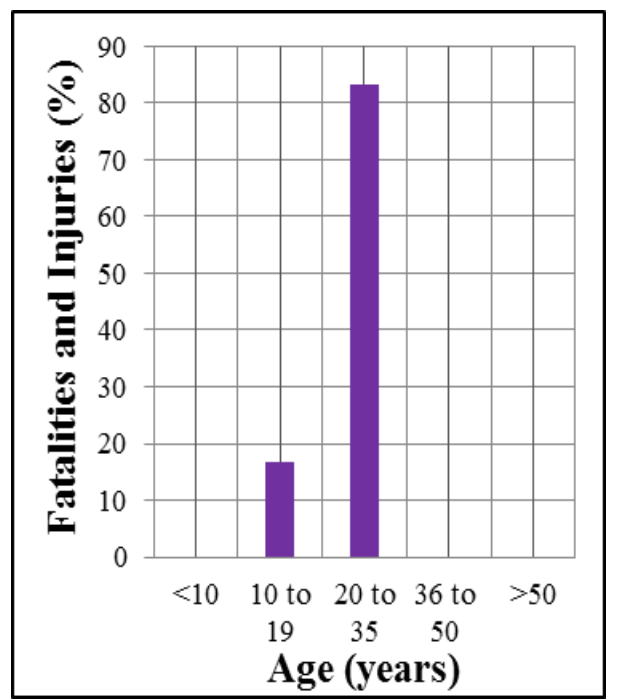

Figure 1(c): Age distribution of motorized road user with respect to the fatalities and injuries $(\%)$. 


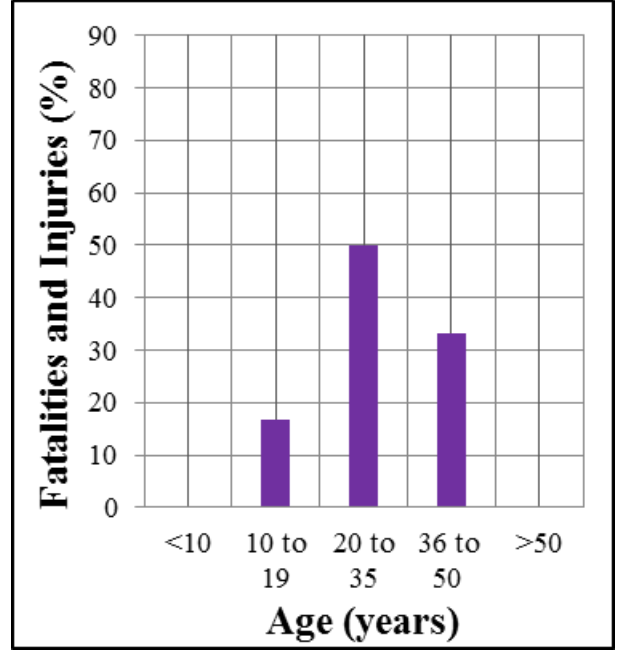

Figure 1(d): Age distribution of NMT road user with respect to the fatalities and injuries (\%).

\subsection{Hourly Distribution of Accidents by Combination of all Police Stations}

Figure 2 shows the hourly distribution of accidents in Rajshahi city. It represents the percentage of accidents occur in different hours of a day. Examining traffic crashes by time shows that about $75 \%$ accidents take place during daytime i.e. 07:00 am to 07:00 pm. Accident frequency increases over the morning hours and remained high from 06:00 am to 10:00 am. The highest accident frequency (15.69\%) is observed in the noon peak at 12:00 pm to 01:00 pm. Almost 25\% of all accidents occurred at night time and over $40 \%$ of all night accidents took place before 12:00 am. It is also seen that no accident occurs at 01:00 am to 02:00 am, 08:00 pm to 09:00 $\mathrm{pm}$ and 10:00 pm to 12:00 am. Time was represented as local time.

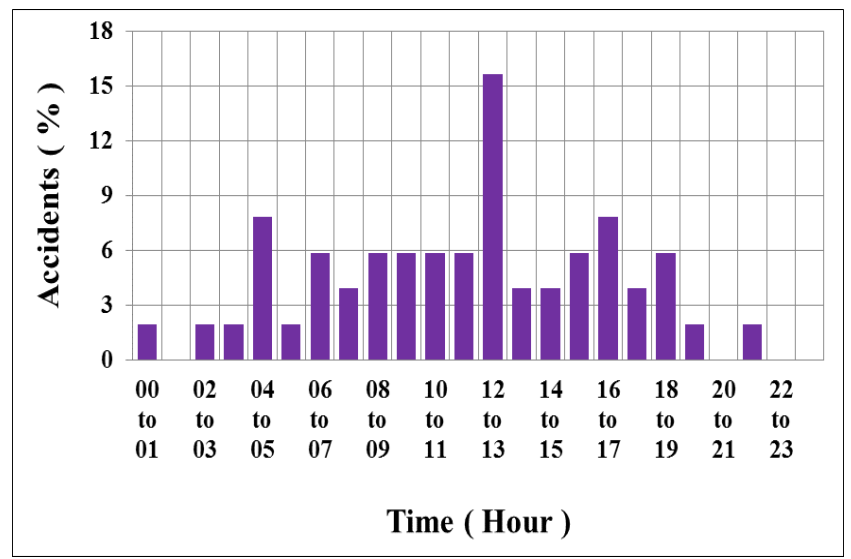

Figure 2: Hourly Distribution of Accidents of Rajshahi city

\subsection{Percentage of Accidents Recorded in Different Police Stations}

Numbers of accidents at several Police Stations are listed in Table 1, where accidents involving fatalities, injuries and property damages are included. It is found that percentage of fatalities is high in Rajpara Police Station which is around $70 \%$. Also it is seen that, highest injury occur in Motihar Police Station and it is about $35.90 \%$ of total accidents. Motihar Police Station is also accounted for highest property damage which is about $20.51 \%$.
Table 1: Traffic Accidents in Different Police Station

\begin{tabular}{|c|c|c|c|c|}
\hline $\begin{array}{c}\text { Police } \\
\text { Station }\end{array}$ & $\begin{array}{c}\text { Fatality } \\
(\%)\end{array}$ & $\begin{array}{c}\text { Injury } \\
(\%)\end{array}$ & $\begin{array}{c}\text { Property } \\
\text { Damage } \\
(\%)\end{array}$ & $\begin{array}{c}\text { Total } \\
(\%)\end{array}$ \\
\hline $\begin{array}{c}\text { Boalia } \\
\text { Model } \\
\text { Police } \\
\text { Station }\end{array}$ & 56.25 & 31.25 & 12.50 & 100 \\
\hline $\begin{array}{c}\text { Motihar } \\
\text { Police } \\
\text { Station }\end{array}$ & 43.59 & 35.90 & 20.51 & 100 \\
\hline $\begin{array}{c}\text { Rajpara } \\
\text { Police } \\
\text { Station }\end{array}$ & 70.00 & 10.00 & 20.00 & 100 \\
\hline $\begin{array}{c}\text { Shah } \\
\text { Mokdum } \\
\text { Police } \\
\text { Station }\end{array}$ & 66.67 & 16.67 & 16.67 & 100 \\
\hline
\end{tabular}

\subsection{Modal Distribution of Total Traffic}

\section{Accidents in Four Police Stations}

From collected data, it is found that truck occurs most of the roadway accidents $(26 \%)$. It is also found that Rickshaw or Van share $4 \%$ of accidents in Rajshahi city compare to other vehicles such as $23 \%$ bus, $14 \%$ bike, and $9 \%$ auto-rickshaw [Figure 3]. Beside these, cycle and micro bus share only $3 \%$ of total accident.

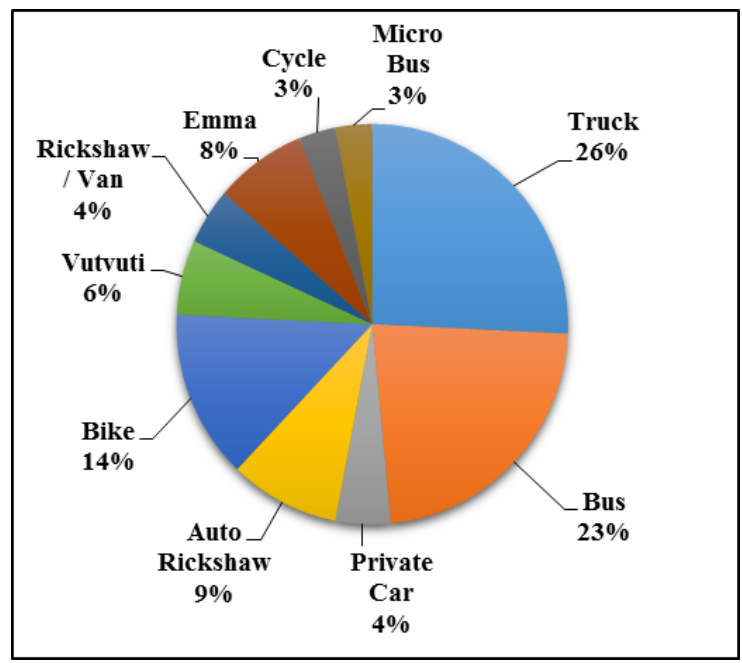

Figure 3: Modal Distribution of Total Traffic Accidents in Four Police Stations

\subsection{Modal Distribution of Total Traffic}

\section{Fatalities in Four Police Stations}

Figure 4 shows the modal distribution of fatalities excluding pedestrian. It is found that Vutvuti share highest fatalities which is $35 \%$ of total fatalities excluding pedestrian. Autorickshaw and rickshaw/van both contribute $19 \%$ of total fatalities where pedestrian do not involve. Beside this bike $(11 \%)$, Emma (8\%) and cycle $(8 \%)$ are also responsible to cause accidents where fatality occurs. It is seen that cycle and Emma are less responsible to fatalities compare to other vehicles. 


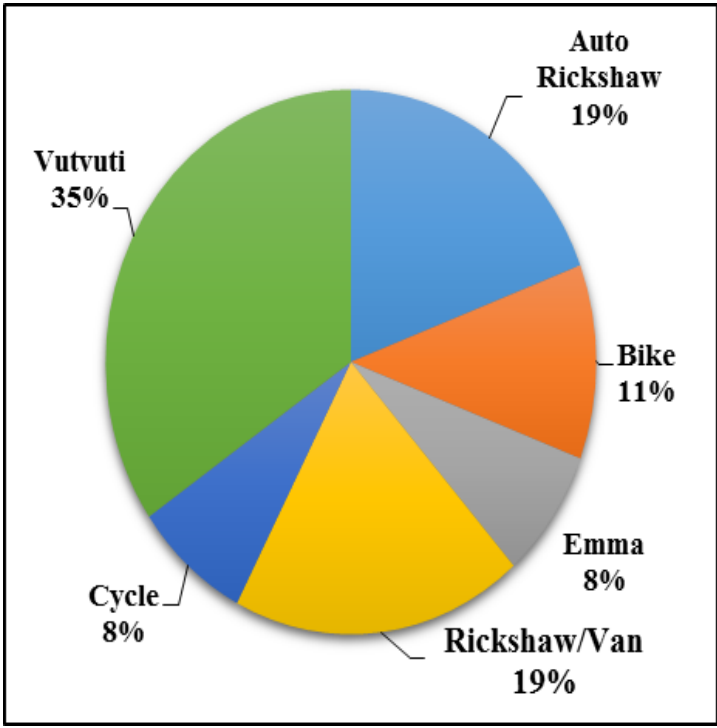

Figure 4: Modal Distribution of Traffic Fatalities Excluding Pedestrians

\subsection{Modal Distribution of Total Pedestrian}

\section{Fatalities}

According to DITS (Greater Dhaka Metropolitan Area Integrated Transport Study), pedestrians contribute the large single victim group of road traffic accident fatalities and injuries [8]. Modal distribution of total pedestrian fatalities of Rajshahi city is represented on Table 2, where it is shown that truck is mostly responsible for total pedestrian fatalities $(32.56 \%)$ and rickshaw is least responsible (2.33\%).

Table 4: Pedestrian Fatalities by Type of Vehicle Involved - Combining of Four Police Stations

\begin{tabular}{|c|c|c|}
\hline \multirow{2}{*}{ Type of Vehicles } & \multicolumn{2}{|c|}{ Accidents } \\
\cline { 2 - 3 } & Fatal (\%) & Non-Fatal (\%) \\
\hline Truck & 32.56 & 21.43 \\
\hline Bus & 23.26 & 25.00 \\
\hline Private Car & 4.65 & 0.00 \\
\hline Auto Rickshaw & 9.30 & 7.14 \\
\hline Bike & 11.63 & 7.14 \\
\hline Vutvuti & 11.63 & 32.14 \\
\hline Rickshaw/Van & 2.33 & 7.14 \\
\hline Emma & 2.33 & 0.00 \\
\hline Micro bus & 2.33 & 0.00 \\
\hline Total & 100 & 100 \\
\hline
\end{tabular}

\subsection{Distribution of Accidents at}

\section{Intersection and Mid-blocks}

During 2011 to 2013, total 51 accidents took place in Rajshahi city. These accidents can be classified based on intersections and mid-blocks which are mentioned in Table 5. About $54.90 \%$ accidents took place in road intersections and $45.10 \%$ accidents took place in road mid-blocks. Among them, higher percentage of accidents took place in the intersection $(23.53 \%)$ and mid-block (15.69\%) of Motihar Police Station.
Table 5: Distribution of Accidents (\%) at Intersection and Mid-blocks in Different Police Stations

\begin{tabular}{|c|c|c|c|}
\hline \multirow{2}{*}{$\begin{array}{c}\text { Police } \\
\text { Station }\end{array}$} & Intersection & Mid-block & \multirow{2}{*}{ Total } \\
\cline { 2 - 3 } & 13.73 & 9.80 & 23.53 \\
\hline $\begin{array}{c}\text { Boalia } \\
\text { Model } \\
\text { Police } \\
\text { Station }\end{array}$ & 23.53 & 15.69 & 39.22 \\
\hline $\begin{array}{c}\text { Motihar } \\
\text { Police } \\
\text { Station }\end{array}$ & 5.88 & 7.84 & 13.73 \\
\hline $\begin{array}{c}\text { Rajpara } \\
\text { Police } \\
\text { Station }\end{array}$ & 11.76 & 11.76 & 23.53 \\
\hline $\begin{array}{c}\text { Shah } \\
\text { Mokdum } \\
\text { Police } \\
\text { Station }\end{array}$ & & 45.10 & 100.00 \\
\hline Total & 54.90 & & \\
\hline
\end{tabular}

\subsection{Most Hazardous Intersections and}

\section{Mid-blocks in Rajshahi city}

The most important segment of this research is to locate most hazardous road intersections and mid-blocks of Rajshahi city which involves accident data, geological information, numerical analysis and drawing. From obtained accident data, the accident frequency was determined. Consequently, the road intersections and mid-blocks having higher accident frequency were identified. The latitude and longitude of the intersections and mid-blocks were measured by using GPS device and listed as tabular form in Table $6 \& 7$.

\subsection{Location of Most Hazardous \\ Intersections}

From collected data, six road intersections of four Police Stations were identified where number of accidents occurred was high. The latitude and longitude of those intersections were measured by GPS device and a map was drawn by GIS software. Table 6 shows the intersections having high accident frequency.

Table 6: Most Hazardous Intersections of Different Police Stations (Numbers)

\begin{tabular}{|c|c|c|c|c|}
\hline \multirow{2}{*}{$\begin{array}{c}\text { Police } \\
\text { Station }\end{array}$} & $\begin{array}{c}\text { Location of } \\
\text { Road } \\
\text { Intersection }\end{array}$ & $\begin{array}{c}\text { Accident } \\
\text { Frequency }\end{array}$ & Latitude & Longitude \\
\cline { 4 - 5 } & & North N & East E \\
\hline $\begin{array}{c}\text { Boalia } \\
\text { Model }\end{array}$ & $\begin{array}{c}\text { Choto } \\
\text { Bongram }\end{array}$ & 2 & $\begin{array}{c}24^{\circ} 23^{\prime} \\
07.99^{\prime \prime}\end{array}$ & $\begin{array}{c}088^{\circ} 37^{\prime} \\
07.50^{\prime \prime}\end{array}$ \\
\cline { 4 - 5 } Police & Rail & 2 & $\begin{array}{c}24^{\circ} 22^{\prime} \\
27.95^{\prime \prime}\end{array}$ & $\begin{array}{c}088^{\circ} 36^{\prime} \\
14.67^{\prime \prime}\end{array}$ \\
\hline \multirow{2}{*}{$\begin{array}{c}\text { Motihar } \\
\text { Police }\end{array}$} & Kapasia & 2 & $\begin{array}{c}24^{\circ} 21^{\prime} \\
34.85^{\prime \prime}\end{array}$ & $\begin{array}{c}088^{\circ} 42^{\prime} \\
01.74^{\prime \prime}\end{array}$ \\
\cline { 4 - 5 } Station & Katakhali & 2 & $\begin{array}{c}24^{\circ} 21^{\prime} \\
55.24^{\prime \prime}\end{array}$ & $\begin{array}{c}088^{\circ} 40^{\prime} \\
25.73^{\prime \prime}\end{array}$ \\
\hline \multirow{2}{*}{ Rajpara } & Kashia- & 3 & $24^{\circ} 23^{\prime}$ & $088^{\circ} 32^{\prime}$ \\
& danga & & $00.64^{\prime \prime}$ & $46.66^{\prime \prime}$ \\
\hline
\end{tabular}




\begin{tabular}{|c|c|c|c|c|}
\hline $\begin{array}{c}\text { Shah } \\
\text { Mokdum }\end{array}$ & $\begin{array}{c}\text { Vugoroil } \\
\text { Mor }\end{array}$ & 3 & $\begin{array}{c}24^{\circ} 25^{\prime} \\
09.08^{\prime \prime}\end{array}$ & $\begin{array}{c}088^{\circ} 36^{\prime} \\
38.54^{\prime \prime}\end{array}$ \\
\hline
\end{tabular}

\subsection{Location Map of Most Hazardous Intersections}

From the information of Table 8, a typical road map of Rajshahi city is drawn by GIS software which show the roadway containing most hazardous intersections [Figure 5]. The road intersections having maximum accident frequency was investigated and then the latitude and longitude of those intersection was measured by GPS device. The shape-file of our study area was digitalized from Google Earth-map. Then, the intersections was located on the map by GIS software with the measured latitude and longitude of those intersections. It is seen that Vugoroil Mor and Kashiadanga intersection both have same accident frequency which is 3 . Also, it is found that Choto Bongram, Rail Station, Kapasia and Katakhali intersection have same accident frequency which is 2 .

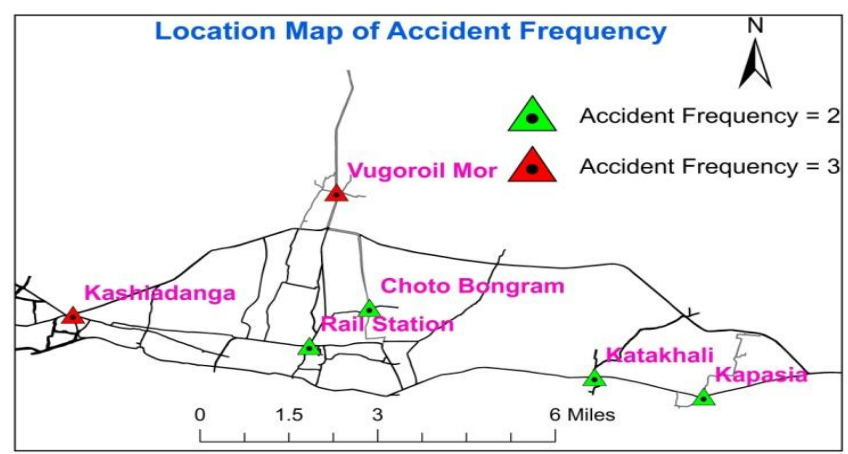

Figure 5: Road Intersections Having Higher Accident Frequency.

\subsection{Location of Most Hazardous Mid- Blocks}

From collected data, four road mid-blocks of four Police Stations were identified where number of accidents occurred was high. The latitude and longitude of those road mid-blocks were measured by GPS device and a map was drawn by GIS software. Table 7 shows the road mid-blocks having high accident frequency. It has been seen that Binodpur Bazar Road is most vulnerable for road accident. In last three years, four fatal accidents occurred in Binodpur Bazar Road.

Table 7: Most Hazardous Mid-blocks of Different Police Stations

\begin{tabular}{|c|c|c|c|}
\hline $\begin{array}{l}\text { Road Mid- } \\
\text { Blocks }\end{array}$ & $\begin{array}{c}\text { Accident } \\
\text { Frequency }\end{array}$ & $\begin{array}{c}\text { Latitude } \\
\text { ( N ) }\end{array}$ & $\begin{array}{c}\text { Longitude } \\
\text { ( E ) }\end{array}$ \\
\hline Bhadra Road & 2 & $\begin{array}{l}24^{\circ} 22^{\prime} \\
21.33^{\prime \prime}\end{array}$ & $\begin{array}{c}088^{\circ} 37^{\prime} \\
20.42^{\prime \prime}\end{array}$ \\
\hline $\begin{array}{c}\text { Binodpur } \\
\text { Bazar Road }\end{array}$ & 4 & $\begin{array}{l}24^{\circ} 22^{\prime} \\
04.24^{\prime \prime}\end{array}$ & $\begin{array}{c}088^{\circ} 38^{\prime} \\
56.93^{\prime \prime}\end{array}$ \\
\hline $\begin{array}{l}\text { Rajpara } \\
\text { Road }\end{array}$ & 2 & $\begin{array}{l}24^{\circ} 22^{\prime} \\
09.82^{\prime \prime}\end{array}$ & $\begin{array}{c}088^{\circ} 34^{\prime} \\
25.8^{\prime \prime}\end{array}$ \\
\hline $\begin{array}{c}\text { Court Darusa } \\
\text { Road }\end{array}$ & 1 & $\begin{array}{l}24^{\circ} 22^{\prime} \\
44.65^{\prime \prime}\end{array}$ & $\begin{array}{c}088^{\circ} 34^{\prime} \\
6.14^{\prime \prime}\end{array}$ \\
\hline
\end{tabular}

\subsection{Location Map of Most Hazardous Mid-Blocks}

From the information of Table 9, a typical map of Rajshahi city is drawn by GIS software which show the roadway containing most hazardous mid-blocks [Figure 6]. The road mid-blocks having maximum accident frequency was investigated and then the latitude and longitude of those road mid-blocks was measured by GPS device. The shape-file of our study area was digitalized from Google Earth-map. Then, the mid-blocks was located on the map by GIS software with the measured latitude and longitude of those mid-blocks. Bhadra Road beginning from Talaimari to Bhadra More which has accident frequency 2, Binodpur Bazar road which occupy from Chowddo-pai to Kajla Gate which has accident frequency 4, Rajpara Road which is from CNB Mor to Rajshahi Court which has accident frequency 2 and Court Darusa Road which is from Hargram to Nawabganj Bypass Bus Stand which has accident frequency 1, are considered as most hazardous road in Rajshahi city.

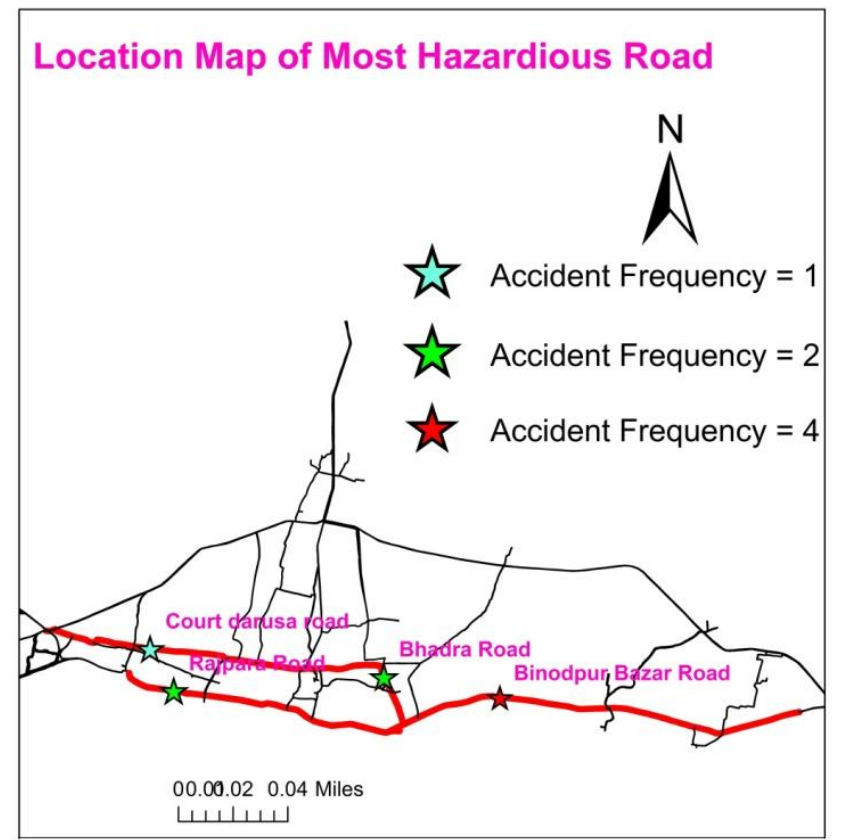

Figure 6: Most Hazardous Road of Rajshahi city with Road Mid-Blocks Having Higher Accident Frequency.

\subsection{Location Map of Most Hazardous Roads and Road Intersections}

A combined map is drawn passing through the location having high accident frequency [Figure 7]. The map is obtained by combining the data from Table 6 and 7. GIS software was used to prepare the map. It indicates six intersections and four road mid-blocks where accident occurs frequently. The six intersections are Choto Bongram, Rail Station, Kapasia, Katakali, Kashiadanga and Vugoroil Mor. Also four mid-blocks are Bhadra Road, Binodpur Bazar Road, Rajpara Road and Court Darusa Road. According to Figure 7, star shape indicates road intersection and tri-angular shape indicate the road mid-blocks where accident frequency is comparatively high. Red color indicates higher accident frequency. Red star shape indicate Binodpur Bazar Road midblocks where accident frequency is 4 . Red tri-angular shape indicate intersection Vugoroil Mor where accident frequency is maximum which is 3 . 


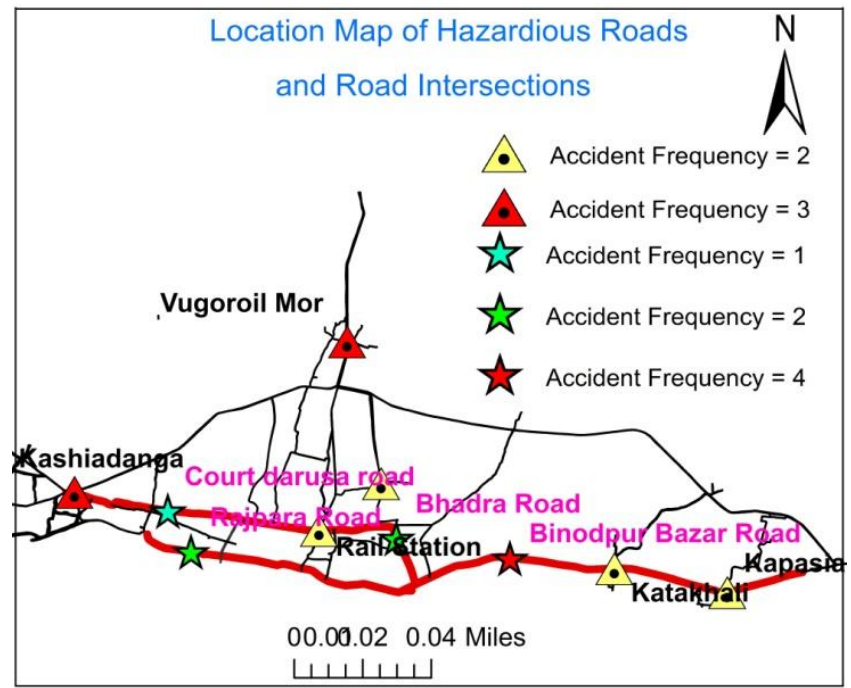

Figure 7: Most Hazardous Road Intersections and Midblocks of Rajshahi city

\section{CONCLUSIONS}

Based on the obtained data, the analysis can be concluded as: 1. From analysis it is found that people ages from 20 to 35 years old are most susceptible to accidents (42\%) and maximum accidents (15.69\%) occur at 12:00 pm to 01:00 pm. It has also been found that trucks involved in $26 \%$ of total accidents where involvement of other vehicles such as buses $23 \%$, bike 14\%, Private Car 4\%, Auto-rickshaw 9\%, Vutvuti $6 \%$, Rickshaw/van 4\%, Emma 8\%, Cycle 3\% and Micro-bus $3 \%$ of total accidents.

2. Maximum fatality (70\%) occurs in Rajpara Police Station, maximum injury (35.90\%) involves in Motihar Police Station and maximum property damage $(20.51 \%)$ takes place in Motihar Police Station.

3. From analysis it is concluded that Choto Bongram, Rail Station, Kapasia, Katakali, Kashiadanga and Vugoroil Mor are most hazardous road intersections of Rajshahi city. Also it is seen that Bhadra Road, Binodpur Bazar Road, Rajpara Road and Court Darusa Road are most hazardous road midblocks of Rajshahi city.

\section{ACKNOWLEDGEMENT}

Authors want to show their utmost gratitude to Omnipotent Allah; without His clemency and blessing, nothing comes true, so does this research. Authors are grateful to the
Rajshahi traffic police authority, for providing accident related data of this research.

\section{REFERENCES}

[1] Sharma, S.K. and Justo, C.E. (2011-2012). Highway engineering, 8th edition, pp. 192.

[2] Mannan, M.S. and Karim, M. (1999). Road accidents in metropolitan Dhaka, Bangladesh. IATSS Research, Vol. 23, No. 2, pp. $90-98$

[3] Murray, C. J. L. and Lopez A.D. (1994). The Global Burden of Disease. A comprehensive assessment of mortality and disability from disease, inquires and risk factors in 1990 and projected to 2020, Harvard University Press. Vol. 1.

[4] Population, total. Retrieved December 12, 2014 from the World Bank Website: http://data.worldbank.org/indicator/SP.POP.TOTL

[5] Bangladesh. Retrieved December 12, 2014 from the Wikipedia: http://en.wikipedia.org/wiki/Bangladesh

[6] Rajshahi District. Retrieved December 12, 2014 from the Wikipedia: http://en.wikipedia.org/wiki/Rajshahi_District

[7] Samshuzzoha A.S.M., Azim M.A., Ullah M.S. (1998) Investigation of intersection of some selected area in Rajshahi city. Under-graduate thesis, Department of Civil Engineering , Rajshahi University of Engineering \& Technology, Rajshahi, Bangladesh.

[8] Hossain M.A., Khan M.E.A. (2001). Study of traffic signal and road marking of Rajshahi city road network. Under-graduate thesis, Department of Civil Engineering , Rajshahi University of Engineering \& Technology, Rajshahi, Bangladesh.

[9] Hoque M.M. (1991). Accident investigation for safety improvement of Dhaka-Aricha highway: A section of Asian highway. Final Report, Department of Civil Engineering, Bangladesh University of Engineering \& Technology, Dhaka, Bangladesh.

[10] Hossain Q.S., Adhikary S.K., Ibrahim W.H.W., Rezaur R. B. (2005). Road traffic accident situation in Khulna city, Bangladesh. Proceeding of the Eastern Asia Society for Transportation Studies, Vol. 5, and pp. 65- 74 . 